\title{
Microbial Isolations from Olive Ridley Sea Turtle (Lepidochelys olivacea) in Alas Purwo National Park, Indonesia
}

\author{
R Sagasiousman ${ }^{1,2}$ and S Khairani ${ }^{3 *}$ \\ ${ }^{1}$ Veterinary Medicine Program, Airlangga University, Campus C Mulyorejo, Surabaya 60115, Indonesia. \\ ${ }^{2}$ Institute of Biology Vaccine, Indonesian Armed Forces, 26 Gudang Selatan Street, Bandung 40113, Indonesia. \\ ${ }^{3}$ Veterinary Medicine Program, Padjadjaran University, Campus Jatinangor Km 21, Sumedang 45363, \\ Indonesia. \\ *Corresponding author: shafia@unpad.ac.id, +6281997779080
}

\begin{abstract}
Infectious diseases in reptiles are one of the biggest causes of morbidity and mortality, related to immunosuppressive factors. Disease in Olive Ridley Sea Turtle arise because ineligible ecosystem in the sea, like bacterial infection. In the world, there are seven species of Sea Turtles, such as: Chelonia mydas, Caretta caretta, Dermochelys coriacea, Eretmochelys imbricata, Natator depressus, Lepidochelys olivacea and Lepidochelys kempii. Six species of Sea Turtles are listed as endangered and are included in the International Union for Conservation of Nature (IUCN) red list. The aim of this study was to identify the bacteria that caused the death of Olive Ridley Sea Turtle. Bacteria were isolated from 15 wounds in the Ridley Olive Turtle in captivity and in the water of breeding ponds, collected using three bacterial growth media, Nutrient Agar with $1 \% \mathrm{NaCl}$, Mac Conkey Agar and Thiosulfate Citrate Bile Salt Agar. Bacteria were isolated by swabs. The results showed that Streptococcus spp., Bacillus subtilis, Aeromonas hydrophila, Citrobacter freundii, Vibrio fluvialis, and $V$. anguillarum were found in Olive Ridley Sea Turtle wounds. Meanwhile, Streptococcus spp., A. hydrophila, and $V$. parahaemolyticus were found in the water of breeding ponds. In conclusion, Streptococcus spp., A. hydrophila, C. freundii, V. fluvialis and V. anguillarum suspected as the cause of death the Olive Ridley Sea Turtle.
\end{abstract}

Keywords: Olive Ridley Sea Turtle, Microbial isolation and identification, Alas Purwo National Park.

\section{INTRODUCTION}

Infectious diseases in reptiles cause high morbidity and mortality, related to immunosuppressive factors [1]. Disease in the Olive Ridley Sea Turtle arises because ecosystems in the sea are not eligible, such as a bacterial infection [2]. In the world, there are seven species of Sea Turtles, such as: Chelonia mydas, Caretta caretta, Dermochelys coriacea, Eretmochelys imbricata, Natator depressus, Lepidochelys olivacea and Lepidochelys kempii. Six species of Sea Turtles are listed as endangered and are included in the International Union for Conservation of Nature (IUCN) red list [3]. Chelonia mydas, Caretta caretta, and Dermochelys coriacea are turtle species found in Indonesian seas and have been listed in Appendix $I$ to the Convention on International Trade in Endangered Wild Fauna and Flora (CITES) [2]. Technical
Guidelines for Management of Turtle Conservation (2009) report that at breeding sites, death of Olive Ridley Sea Turtle (Lepidochelys olivacea) is common. Olive Ridley Sea Turtles (Lepidochelys oliveceae) are often attacked by diseases caused by bite wounds that usually occur in the breeding system, bacterial and fungal infections, cloacal infections, protrusion of the digestive tract and algal growth [4]. There are several diseases associated with skin injuries that can infect the Sea Turtle Olive Ridley in captivity such as aggressive bites and Focal Erosive Dermatitis (FED). Previous studies have reported that Aeromonas formicans, Vibrio anguillarum, $V$. alginolyticus and Citrobacter freundii infect turtles [5]. Microbial isolation from the Olive Ridley Sea Turtle (Lepidochelys oliveceae) in Alas Purwo National Park became very interesting to study. 


\section{MATERIAL AND METHOD}

This research was conducted at the Bacteriology and Mycology Laboratory, Faculty of Veterinary Medicine, Airlangga University. Sampling of 15 wound samples from Olive Ridley Sea Turtle was carried out in captivity of the Olive Ridley Sea Turtle, Alas Purwo National Park, Indonesia from 12 July to 12 August 2013. Sampling was carried out for 14 days, swab samples from wounds on the neck, fins and eye and water samples in the breeding ponds. Swab samples were put into glycerin phosphate solution, then grown on NA $1 \%$ $\mathrm{NaCl}, \mathrm{MCA}$ and TCBS fertilizing media. Biochemical tests were carried out by inoculating bacterial culture on Mac Conkey media, thiosulfate

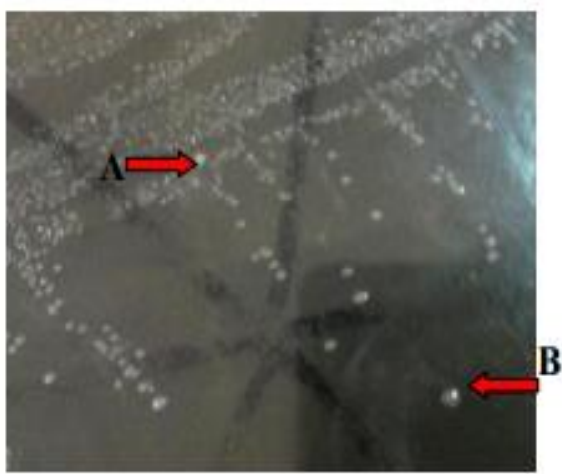

Citrate Bile Salt Agar and Nutrient order 1\% Urea $\mathrm{NaCl}$ into media, citrate, Motility Indol sulfide (SIM), Triple Iron Iron Agar (TSIA), Methyl Red (MR), Voges Proskauer (VP) and carbohydrate fermentation (glucose, sucrose, mannitol, lactose, maltose) [6]. Samples were incubated at $37^{\circ} \mathrm{C}$ for 18-24 hours. Isolation and identification of bacteria were carried out based on the morphology of bacterial colonies that grew on the medium and were confirmed using key identification of biochemical tests [7-9].

\section{RESULT AND DISCUSSION}

The results showed that 7 different bacteria were found from 15 wound swabs and water samples in the Olive Ridley Sea Turtle breeding ponds

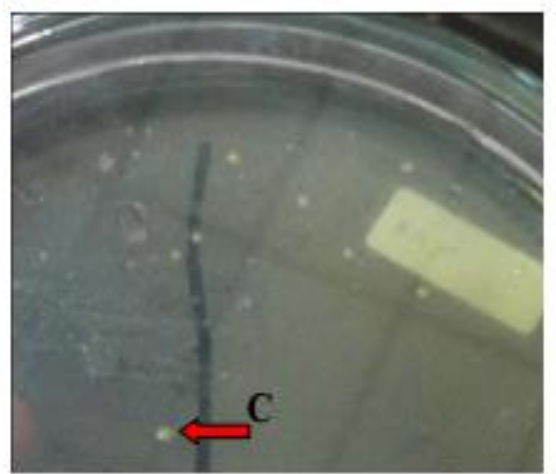

Figure 1 : Colonies on NA $1 \% \mathrm{NaCl}$ media. Description: A. The round shape protruding, convex elevation, smooth edges and white color. B. The round shape protruding, convex elevation, smooth edges and clear colors. C. The round shape protruding, convex elevation, smooth edges and a yellowish white color. 

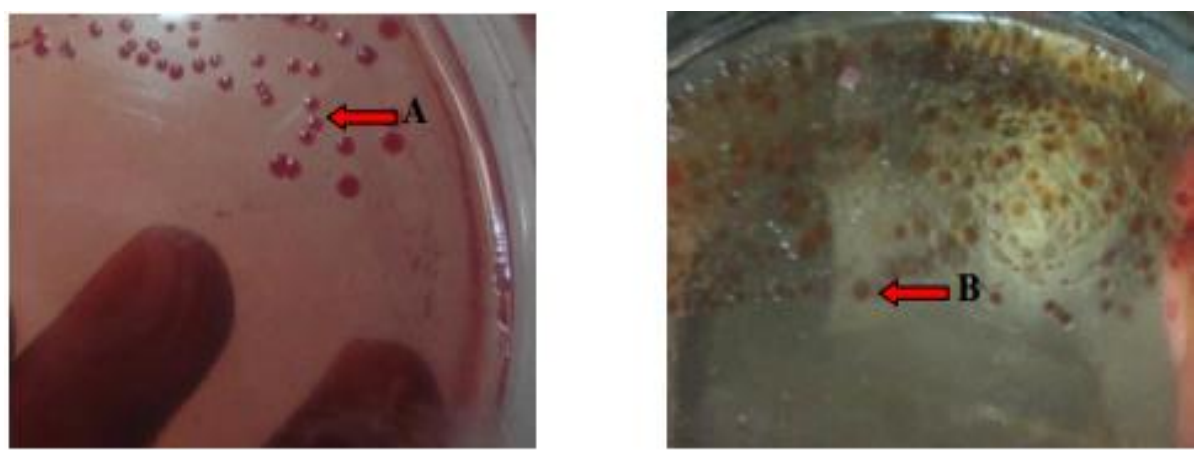

Figure 2 : Colonies on MCA media. Description: A. The round shape protruding, convex elevation, smooth edges and red $\mathbf{B}$. The round shape protruding, convex elevation, smooth edges and brown.
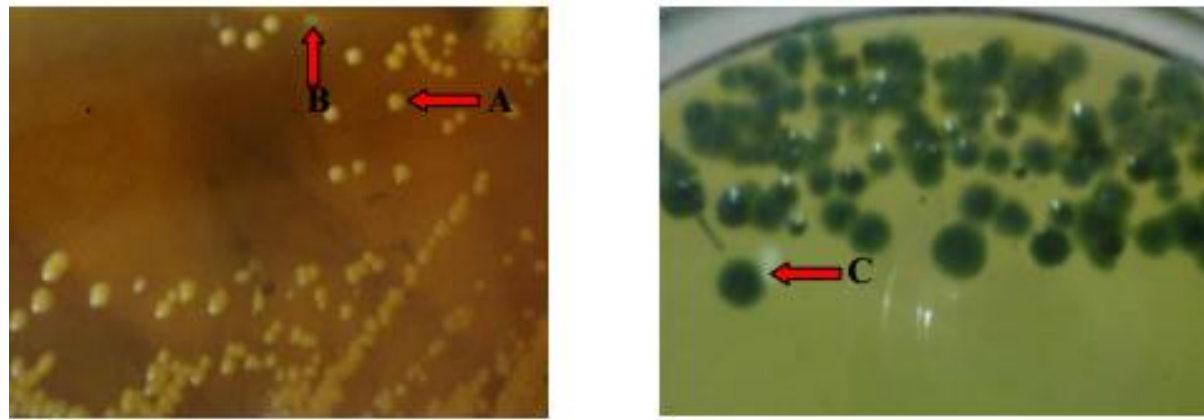

Figure 3 : Colonies on TCBS media. Description: A. The round shape protruding, convex elevation, smooth edges and yellow colors. B. The round shape protruding, convex elevation, smooth edges and clear yellow color. C. The round shape protruding, convex elevation, smooth edges and green.
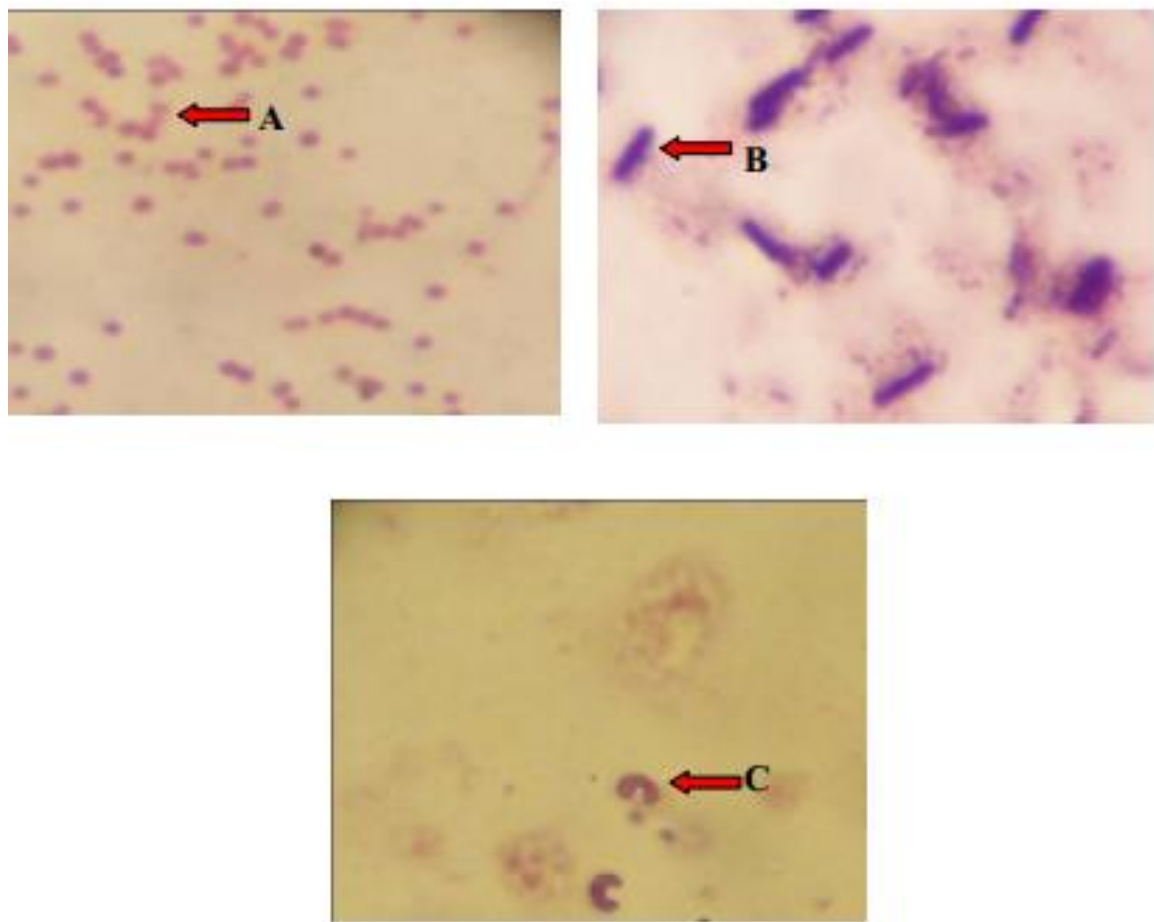
Figure 4 : Gram staining at NA $1 \% \mathrm{NaCl}$ media (Description: A. Gram positive -spherical shape. B. Gram positive - rod form. C. Gram negative - comma shape. Olympus CX22 : 1000x magnification.

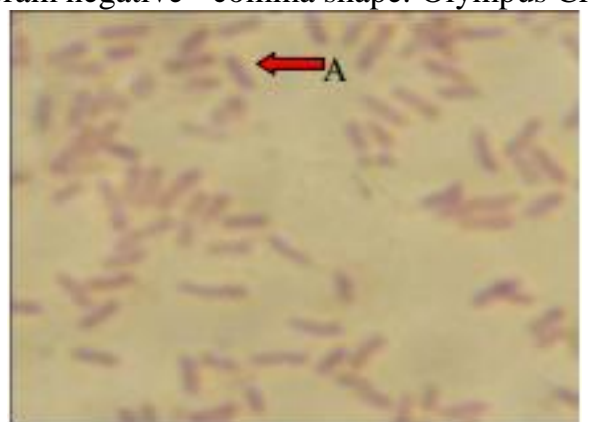

Figure 5 : Gram staining on MCA media. Description: A. Gram-negative rod form. Microscope with 4000x magnification.

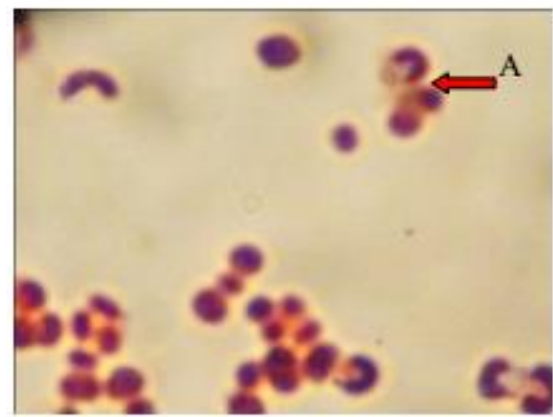

Figure 6 : Gram staining on TCBS media. Description: A. Gram-negative form comma - 4000x magnification.

Table 1 : Biochemical Result from Colonies in NA 1\% NaCl Media.

\begin{tabular}{|c|c|c|c|c|c|c|c|c|c|c|c|}
\hline \multirow{2}{*}{$\begin{array}{l}\text { Colonies } \\
\text { Colour }\end{array}$} & \multicolumn{11}{|c|}{ Biochemical Test } \\
\hline & Ureum & SCA & SIM & MR & VP & TSI-A & Lac & Man & Glu & Mal & Suc \\
\hline Clear & - & + & Motil Indol (-) & + & + & $\begin{array}{c}\mathrm{A} / \mathrm{A} \\
\text { Gas (-), } \mathrm{H}_{2} \mathrm{~S}(-)\end{array}$ & + & + & + & + & + \\
\hline White & + & + & $\begin{array}{l}\text { Non motil } \\
\text { Indol (-) }\end{array}$ & - & - & $\begin{array}{c}\mathrm{A} / \mathrm{A} \\
\mathrm{Gas}(-), \mathrm{H}_{2} \mathrm{~S}(-)\end{array}$ & + & - & + & + & + \\
\hline Cream & - & - & Motil Indol (-) & + & + & $\begin{array}{c}\text { A/A } \\
\text { Gas (-), } \mathrm{H}_{2} \mathrm{~S}(-)\end{array}$ & + & + & + & + & + \\
\hline
\end{tabular}

Annotation : (+) Active; (-) Non Active; A/A (Alcali / Alcali); SCA (Simon Citrat Agar); SIM (Sulfid Indol Motility); MR (Methil Red); VP (Voges Proskauer); TSI-A (Triple Sugar Iron Agar), Lac (Lactose); Man (Manitol); Glu (Glucose); Mal (Maltose); Suc (Sucrose).

Table 2 : Biochemical Result from Colonies in MCA Media.

\begin{tabular}{|c|c|c|c|c|c|c|c|c|c|c|c|}
\hline \multirow{2}{*}{$\begin{array}{l}\text { Colonies } \\
\text { Colour }\end{array}$} & \multicolumn{11}{|c|}{ Biochemical Test } \\
\hline & Ureum & SCA & SIM & MR & VP & TSI-A & Lac & Man & Glu & Mal & Suc \\
\hline Red & + & + & Motil Indol (-) & - & + & $\begin{array}{c}\text { B/A } \\
\text { Gas (-), } \mathrm{H}_{2} \mathrm{~S}(-)\end{array}$ & - & - & + & + & + \\
\hline Pink & - & + & $\begin{array}{c}\text { Motil } \\
\text { Indol (-) }\end{array}$ & - & - & $\begin{array}{c}\mathrm{B} / \mathrm{A} \\
\operatorname{Gas}(-), \mathrm{H}_{2} \mathrm{~S}(-)\end{array}$ & + & + & + & + & - \\
\hline
\end{tabular}

Annotation : (+) Active; (-) Non Active; A/A (Alcali / Alcali); SCA (Simon Citrat Agar); SIM (Sulfid Indol Motility); MR (Methil Red); VP (Voges Proskauer); TSI-A (Triple Sugar Iron Agar), Lac (Lactose); Man (Manitol); Glu (Glucose); Mal (Maltose); Suc (Sucrose). 
Table 3 : Biochemical Result from Colonies in TCBS Media.

\begin{tabular}{|c|c|c|c|c|c|c|c|c|c|c|c|}
\hline \multirow{2}{*}{$\begin{array}{c}\text { Colonies } \\
\text { Colour }\end{array}$} & \multicolumn{11}{|c|}{ Biochemical Test } \\
\hline & Ureum & SCA & SIM & MR & VP & TSI-A & Lac & Man & Glu & Mal & Suc \\
\hline Yellow & - & - & Motil Indol (-) & + & + & $\begin{array}{c}\mathrm{A} / \mathrm{A} \\
\text { Gas (-), } \mathrm{H}_{2} \mathrm{~S}(-)\end{array}$ & + & + & + & + & + \\
\hline $\begin{array}{l}\text { Yellow } \\
\text { Clear }\end{array}$ & - & - & $\begin{array}{c}\text { Motil } \\
\text { Indol (-) }\end{array}$ & $\begin{array}{l}(+) \\
\text { low }\end{array}$ & - & $\begin{array}{c}\mathrm{A} / \mathrm{A} \\
\text { Gas (-), } \mathrm{H}_{2} \mathrm{~S}(-)\end{array}$ & + & - & + & + & + \\
\hline Green & - & - & Motil Indol (-) & + & + & $\begin{array}{c}\text { B/A } \\
\text { Gas (-), } \mathrm{H}_{2} \mathrm{~S}(-)\end{array}$ & - & + & + & + & - \\
\hline
\end{tabular}

Annotation : (+) Active; (-) Non Active; A/A (Alcali / Alcali); SCA (Simon Citrat Agar); SIM (Sulfid Indol Motility); MR (Methil Red); VP (Voges Proskauer); TSI-A (Triple Sugar Iron Agar), Lac (Lactose); Man (Manitol); Glu (Glucose); Mal (Maltose); Suc (Sucrose).

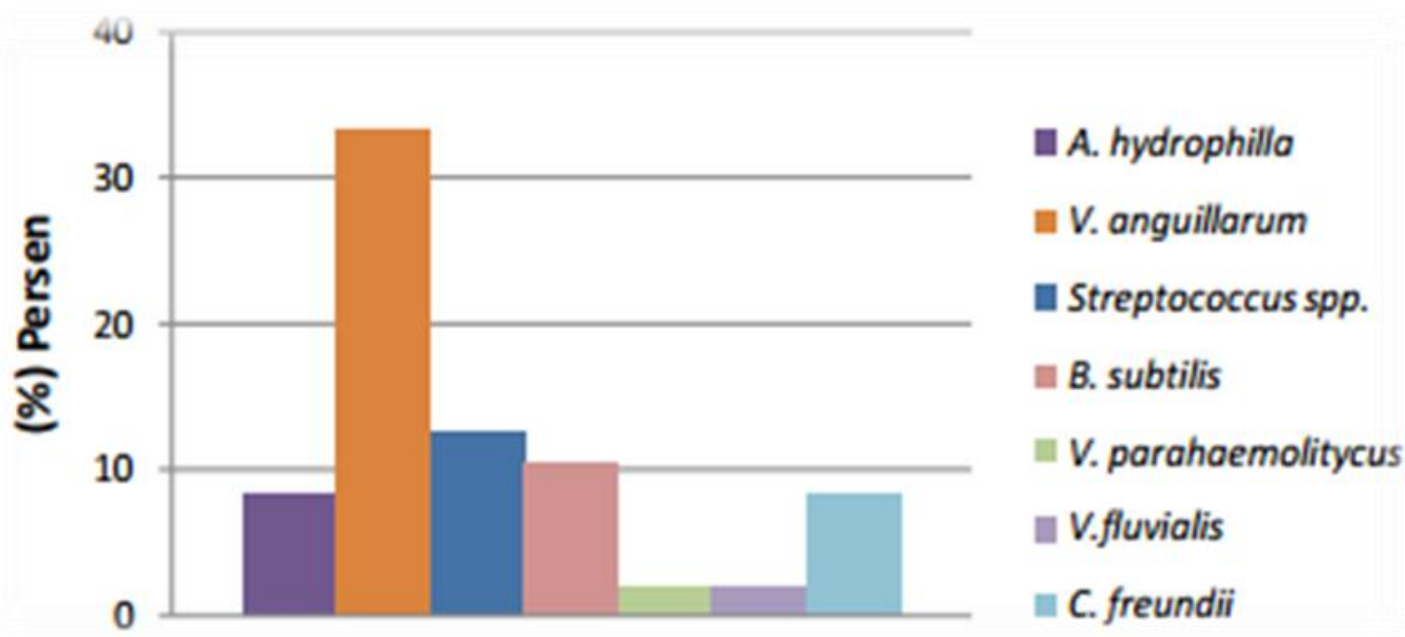

Figure 7 : Microbial species from Olive Ridley Sea Turtle in Alas Purwo National Park.

7 species of bacteria found in this study, such as: Streptococcus spp., Bacillus subtilis., Aeromonas hydrophila, Cirobacter freundii, Vibrio fluvialis and $V$. anguillarum in Ridley Olive Sea Turtle wounds, while Streptococcus spp., A. hydrophila and $V$. parahaemolyticus were found in water samples. Streptococcus spp., Aeromonas hydrophila, Vibrio fluvialis and $V$. anguillarum are found in more than $30 \%$ of turtle wounds. This result is supported by previous studies, microorganisms that are highly pathogenic to fish are Aeromonas spp., Pseudomonas spp., Plesiomonas sp., Vibrio spp. and Streptococcus spp [10]. A hydrophila is often a cause of Motile Aeromonas Septicemia (MAS) in African catfish and can also cause disease in amphibians, reptiles, birds, mammals and humans [11] through open wounds, ingested with water or food. $V$. anguillarum can directly cause illness and death [12]. Citrobacter freundii, gram-negative rodshaped often a significant cause of opportunistic infections. Streptococcus spp. is a bacterium that is widespread in the world, found on the skin, mucous membranes, human and animal intestines, while the bacterium $B$. subtilis is found in nature and is widespread in soil, water and water [4].

Several factors that cause bacterial infections in Olive Ridley Sea Turtle wounds are: 1). there is direct contact between the turtle keeper and Olive Ridley Sea Turtle when moving it from the breeding pond to the tank, so that bacterial contamination from the hands of the turtle keeper is very possible. Direct contact like this can be overcome by using gloves optimally. 2). Bacterial infection in the environment, it becomes very important to note especially relating to the maintenance system in breeding ponds. 3). Water circulation system, in captivity Alas Purwo is done manually by drying pool water and replacing pool water with fresh water every day. This is certainly not optimal. 4). Water quality, water is a very important life medium for Olive Ridley Sea Turtles. The parameters seen in this study are $\mathrm{pH}$ and temperature of water maintenance. The results showed that the temperature range of pond is 21$25^{\circ} \mathrm{C}$ and the $\mathrm{pH}$ is 9 . Bacteria that can live in pond are alkalophilic bacteria that can survive at a $\mathrm{pH}$ of 8.4 to 9.5 [5]. 5). Pool Area, it is also caused a 
bacterial infection that can cause the death of the Olive Ridley Sea Turtle. a large pool will certainly provide plenty of room for the turtle, because the Olive Ridley Sea Turtle is an active animal [15]. 6). Aggressive behavior, aggressive bites often occur in the Olive Ridley Sea Turtle group and often cause serious physical damage and cause injury [12]. Wounds are media that can be used by pathogenic microorganisms to enter the turtle's body and became a predisposing factor to bacterial contamination that can cause the death of Olive Ridley Sea Turtle.

\section{CONCLUSSION}

The conclusion of this study, there were 7 bacteria that were isolated and identified such as: Streptococcus spp., Bacillus subtilis, Aeromonas hydrophila, Citrobacter freundii, Vibrio fluvialis, $V$. anguillarum and $V$. parahaemolyticus. Bacterial contamination of the wound is one of the predisposing factors for Olive Ridley Sea Turtle death in Alas Purwo National Park.

\section{REFERENCES}

[1] Balley, T. 2008. Mortality At A Hawskbill Turtle (Eretmochelys imbricate) Rearing Center. Wildlife Middle East News. Vol. 3. Issue 2. 1.

[2] Buller, N. B. 2004. Bacteria from fish and other aquatic animals. A practical identification manual. CABI publishing. Department of agriculture, South perth. Western Australia.

[3] Aslamsyah, S., H. Y. Azis, Sriwulan dan K. G. Wiryawan. 2009. Mikroflora Saluran Pencernaan Ikan Gurame (Osphronemus gouramy Lacepede). Torani (Jurnal ilmu Kelautan dan Perikanan) Vol. 19 (1) April 2009: 6673.

[4] Brooks. G. F., J. S. Butel, and S. A. Morse. 1994, Mikrobiologi Kedokteran Edisi 2, Penerbit buku Kedokteran EGC, Jakarta.

[5] Direktorat Konservasi dan Taman Nasional Laut, Direktorat Jenderal Kelautan, Pesisir dan Pulau-Pulau Kecil, Departemen Kelautan dan Perikanan RI, 2009. Pedoman Teknis Pengelolaan Konservasi Penyu. Jakarta Pusat. Indonesia.

[6] Feliatra. 1999. Identifikasi Bakteri Patogen (Vibrio sp) Di Perairan Nongsa Batam propinsi Riau. J. Natur Indonesia II (I). 31.

[7] Flint. M., J. C. Patterson-Kane., C. J. Limpus., T. M. Work., D. Blair, and P. C. Milis. 2009. Postmortem diagnostic investigation of disease in freeranging marine turtle populations: a review of common pathologic findings and protocols. J Vet Diagn Invest 21: 734.

[8] Kamaludin, I. 2011. Efektivitas Ekstrak Lidah Buaya Aloe vera Untuk Pengobatan Infeksi Aeromonas hydrophila Pada ikan Lele Dumbo Calrias sp. Melalui pakan [SKRIPSI]. Fakultas Perikanan Dan Ilmu Kelautan. Institut Pertanian Bogor.

[9] Leong, J. K., D. L. Smith, D. B. Revera, Lt. J. C. Clary III, D. H. Lewis, J. L. Scott, and A. R. DiNuzzo. 1989. Health Care and Disease of Captive Reared Loggerhead and Kemp's Ridley Sea Turtles. National Marine Fisheries Service. A\&M University, Victoria, The university of texas medical branch. Texas.

[10] Mader, D. R. 2006. Reptile Medicine and Surgery. Second Edition. W.B. Saunders Company. Florida.

[11] Naulita, Y. 1990. Telaah Laju Pertumbuhan Anak Penyu Hijau (Chelonia mydas L.) Pada Pemberian Makanan Yang Berbeda [Karya Ilmiah]. Fakultas Perikanan. Institut Pertanian Bogor.

[12] Rajagopalan, M., M. Vijayakumaran, and A. F. Fernando. 1984. Some Health Problems Observed in the Olive Ridley Sea Turtle and Juveniles of Sea Turtles n Captivity. CMPRI Bulletin. Sea turtle Research.

[13] Reichart, H. A. 1993. Synopsis of Biological Data on the Olive Ridley Sea Turtle Lepidochelys olivacea (Eschscholtz 1829) in the western Atlantic. NOAA Tech. Memo. NMFS-SEFSC-336. U.S. Dept. of Commerce.

[14] Suyati. 2010. Identifikasi dan Uji Antibiotik Bakteri Gram Negatif Pada sampel Urin Penderita Infeksi Saluran Kemih (ISK) [SKRIPSI]. Fakultas Matematika dan Ilmu Pengetahuan Alam. Universitas Negeri Papua. Tomascik, T., A. J. Mah, A, and M. K. Moosa. 1997. The Ecology of Indonesian Seas. Periplus Volumes 2.

[15] Woodland, J. 2004. Chapter 5 Bacteriology. NWFHS Laboratory Procedures Manual Second Edition. Arizona. 